\title{
NORTHWEST LIMIT OF THE BREEDING RANGE OF THE RUDDY DUCK
}

\author{
BRYCE C. LAKE, U.S. Fish and Wildlife Service, Yukon Flats National Wildlife Ref-
} uge, $10112^{\text {th }}$ Avenue, Room 264, Fairbanks, Alaska 99701; bryce_lake@fws.gov

This note describes the status of the Ruddy Duck (Oxyura jamaicensis) as breeding in Alaska and updates the northwest extent of the species' breeding range in North America. That distribution now includes wetlands just south of the Arctic Circle, within the Yukon Flats National Wildlife Refuge (NWR).

The earliest records of the Ruddy Duck in Alaska reflected a sporadic occurrence, but the species is now considered annual but rare in the state (Checklist of Alaska Birds, 25 $5^{\text {th }}$ ed., 2019; www.universityofalaskamuseumbirds.org/products/checklist. pdf). The first sighting was of two birds at Kupreanof Island, southeast Alaska, near Petersburg, on 15 August 1916 (Willett 1921), but the species was not sighted again until 1959, when the first breeding was noted, at Tetlin Lakes in the eastern Interior (Hansen 1960; see Gibson and Withrow 2015:95 for a map defining Alaska's geographic regions). Between 1959 and 1996 most Alaska breeding records were from the eastern Interior, with a single sighting as far west as Minto Lakes, in 1963 (Kessel and Springer 1966). Most recent broods have been found farther north in the Interior (Yukon Flats NWR, 1997-2018) than previously described, or farther south, south of the Alaska Range, in south-central Alaska (Kenney Lake, 2005-2018). The northernmost sightings of Ruddy Duck broods motivated me to summarize the record of the Ruddy Duck breeding in Alaska, and I have organized records by region and year of sighting. For the Yukon Flats NWR, I have also referred to efforts that produced no sightings of Ruddy Ducks.

Four Ruddy Duck broods were observed in the eastern Interior in four years from 1959 to 1993 (Figure 1). The first was at Tetlin Lakes on 25 August 1959 (Hansen 1960). At wetlands north of the Northway airport, a female with two downy young was observed on 25 July 1987 (Gibson et al. 1987), a juvenile almost certainly reared locally was observed on 26 August 1992 (Tobish and Isleib 1993), and a female with seven ducklings was observed 26-28 June 1993 (Tobish 1993). In the central Interior, a single brood was noted at Minto Lakes 21 July 1963 (Figure 1, Kessel and Springer 1966).

In south-central Alaska, Ruddy Duck broods were observed at Kenney Lake in eight years from 2005 to 2018 (Figure 1). The first sighting was of three females and 13 ducklings on 3 August 2005 (Tobish 2006; A. Lang pers. comm.). Three broods were observed 12-19 August 2006 (Tobish 2007), four females and five ducklings were seen 4 August 2007 (Tobish 2008), and four females with seven ducklings were seen from 24 June to 13 July 2009 (Tobish 2010). A single female with 12 ducklings was present 24 July 2010 (Tobish 2011), and several broods were reported there in September 2011 (Tobish 2012). On 22 July 2017, a female with three downies was observed (www.eBird.org, Z. Pohlen pers. comm.), and on 22 July 2018, a female with four ducklings (eBird, S. Schuette pers. comm.).

In the northern Interior, U.S. Fish and Wildlife Service (USFWS) personnel surveyed duck broods in July 1965-1971, 1973, 1974, and 1981 on up to 35 wetlands distributed across the $35,000 \mathrm{~km}^{2}$ of Yukon Flats NWR. No Ruddy Duck broods were observed (Shively and Lake 2009). From May to September 1985-1989 the duck-brood surveys expanded to cover 106 wetlands (Heglund 1992). Just a single observation of an adult Ruddy Duck was noted, with no evidence of young (P. Heglund pers. comm.). Duck-brood surveys by ground and helicopter crews covered $202 \mathrm{~km}^{2}$ in July and August 1992 but revealed no Ruddy Duck broods (USFWS unpubl. data). In 1997, the first observation of a brood was made, of a female with seven ducklings 


\section{NOTES}

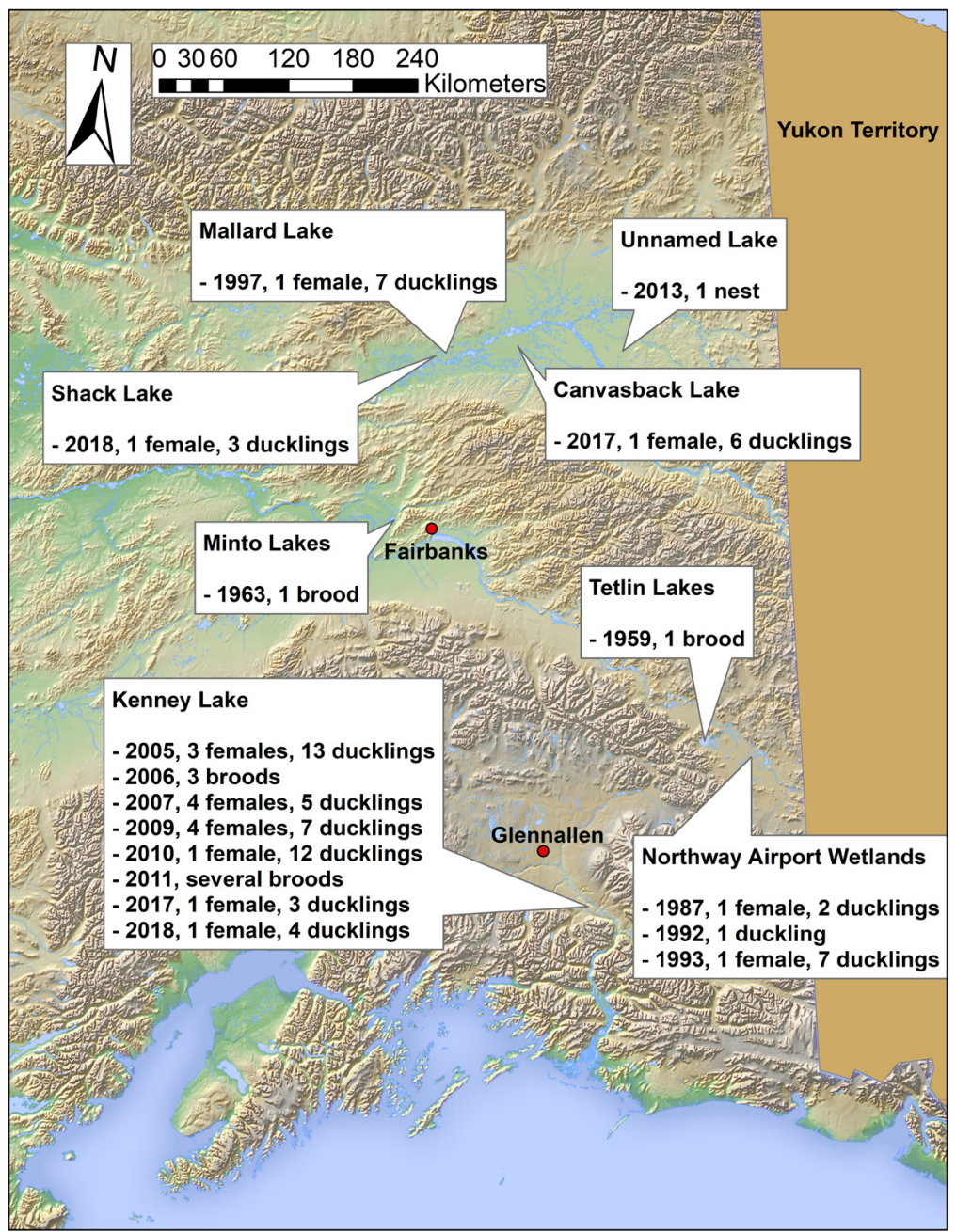

Figure 1. Locations of broods or nests of the Ruddy Duck observed in Alaska, 1959-2018.

at Mallard Lake (K. Sowl pers. comm.). In August 1998, a helicopter-based brood survey of 32 wetlands in southern Yukon Flats yielded five adult Ruddy Ducks but no broods (Person and Bertram 1999). Searches for duck nests at Scoter Lake (66.243 ${ }^{\circ}$ N, $146.394^{\circ}$ W) from June to August 2002-2004 revealed no Ruddy Duck nests (D. Safine pers. comm.). Nest searches at Shack Lake (Figure 1) from 2005 to 2008 yielded observations of multiple pairs, but no counts were recorded and no broods were observed (K. Martin pers. comm.). Surveys of 72 wetlands across the Yukon Flats from June to August 2010-2012 (Lewis et al. 2015) recorded at least one adult Ruddy Duck in 13 instances but zero broods. In 2013, however, a Ruddy Duck 


\section{NOTES}

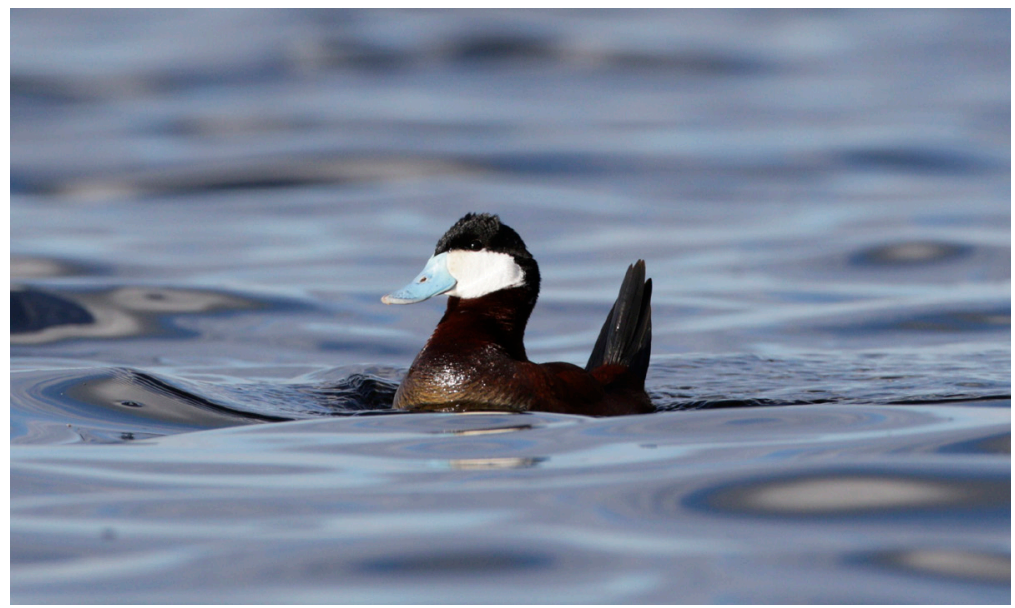

Figure 2. Male Ruddy Duck at Canvasback Lake, Yukon Flats National Wildlife Refuge, Alaska, 1 June 2017.

Photo by Adam Grimm/U.S. Fish and Wildlife Service

nest was discovered at an unnamed wetland at $66.364^{\circ} \mathrm{N}, 144.252^{\circ} \mathrm{W}$ (Figure 1). Adults had previously been observed at this wetland in 2011 and 2012 (Lewis et al. 2015, T. Lewis pers. comm.). In 2017, a brood of six ducklings of class 1B (Gollop and Marshall 1954) was observed at Canvasback Lake (Figures 1 and 2, USFWS, unpubl. data). In 2018, a brood of three class 1A ducklings was observed at Shack Lake (Figures 1 and 3, USFWS, unpubl. data).

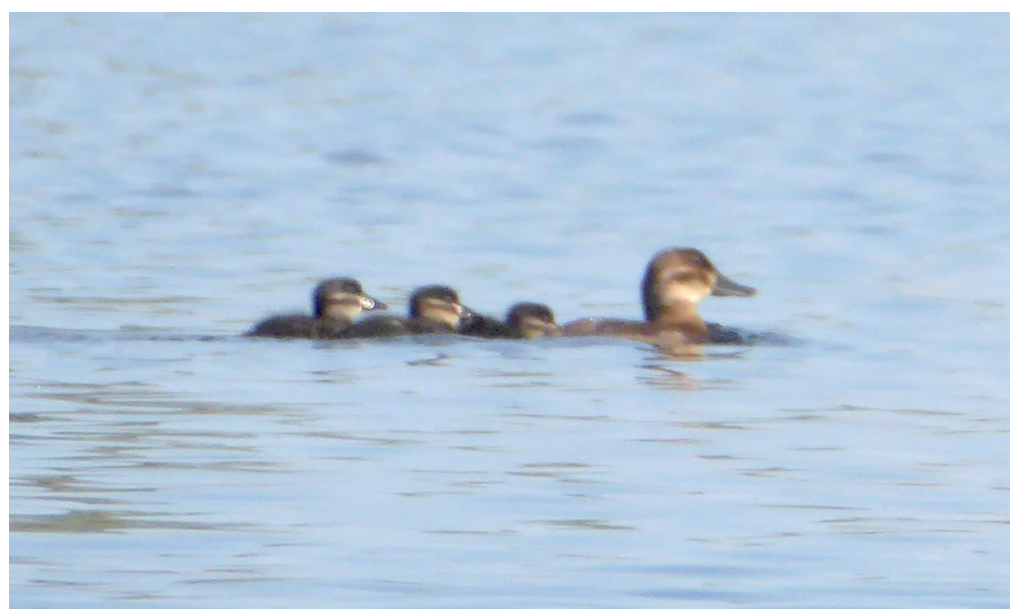

Figure 3. Female Ruddy Duck with three young at Shack Lake, Yukon Flats National Wildlife Refuge, Alaska, 25 July 2018.

Photo by Michelle Lake/U.S. Fish and Wildlife Service 


\section{NOTES}

Thus the currently known Alaska breeding distribution of the Ruddy Duck includes (1) Kenney Lake at the southern margin of the boreal forest, in south-central Alaska, and (2) wetlands just below the Arctic Circle on the Yukon Flats NWR. The latter records represent the northwest limit of the species' breeding range in North America. Notably, no Ruddy Duck broods have been observed recently at the sites of the earliest breeding records. Perhaps the species has simply moved away from the highway system in the eastern Interior, where three of the four instances of breeding in the region were recorded. In Tetlin NWR, though staff surveying wetlands distant from the highway did not report any broods, they did encounter single individuals and pairs in most years from 1988 to 2013 (N. Berg pers. comm.). Thus the Ruddy Duck could just be passing through that region en route to new habitat (Hansen 1960).

On the Yukon Flats NWR, sightings of pairs and single birds became regular and widespread around 2010. Ruddy Ducks are now seen annually on some of the refuge's wetlands. The species is now also observed annually in other parts of Alaska, as around Fairbanks (eBird). Two instances of Ruddy Duck breeding in Yukon Territory have been documented (Sinclair et al. 2003), and pairs are now reported there regularly (eBird). During aerial surveys (1957-2018) of Alaska, pairs and single Ruddy Ducks were recorded sporadically except on the tundra of the north and northwest (U.S. Fish and Wildlife unpubl. data). Thus the species may extend its breeding range further. Similar boreal wetland habitat exists to the west of the current range in the Innoko, Tanana, Kanuti, Nowitna, and Kokukuk regions and farther south in some of the Kenai Peninsula.

It is unclear why the range of Ruddy Duck has spread north in Alaska. The earliest records in the Interior were "apparently a result of displacement from drought-affected prairies" (Kessel and Gibson 1978:24), but perhaps a longer ice-free period in some years has been favorable, as it has been for the Trumpeter Swan (Cygnus buccinator, Schmidt et al. 2009). Therefore, like the ranges of some landbirds such as the Yellow-bellied Flycatcher (Empidonax flaviventris; Martin et al. 2006), Common Yellowthroat (Geothlypis trichas; Winker and Gibson 2018), and Cassin's Vireo (Vireo cassinii; DeCicco and Hajdukovich 2008), the ranges of some other species of waterfowl are probably expanding as well, a topic worthy of further investigation.

T. Tobish located birds, diligently recorded observations, and graciously provided a compilation of past Ruddy Duck sightings to me. The following individuals also provided information on the Ruddy Duck in Alaska: N. Berg, J. Bryant, L. Devaney, K. Dubour, J. Fischer, P. Heglund, H. Johnson, M. Lake, A. Lang, C. Latty, T. Lewis, K. Martin, M. Miller, M. Petrula, Z. Pohlen, J. Roach, D. Safine, S. Schuette, and K. Sowl. D. Groves provided data from aerial counts of Ruddy Ducks across Alaska from 1957 to 2018. L. DeCicco, S. Heinl, and R. Scher provided comments that improved the note.

\section{LITERATURE CITED}

DeCicco, L. H., and Hajdukovich, N. 2008. First record of the Cassin's Vireo nesting in Alaska. W. Birds 39:36-38.

Gibson, D. D., and Withrow, J. J. 2015. Inventory of the species and subspecies of Alaska birds, second edition. W. Birds 46:94-185.

Gibson, D. D., Tobish, T. G. Jr., and Isleib, M. E. 1987. Alaska region (summer 1987). Am. Birds 41:1475-1477.

Gollop, J. B., and Marshall, W. H. 1954. A guide for aging duck broods in the field. Bureau of Sport Fisheries and Wildlife, U.S. Dept. Interior, Minneapolis.

Hansen, H. A. 1960. Changed status of several species of waterfowl in Alaska. Condor 62:136-137; doi 10.2307/1365678. 


\section{NOTES}

Heglund, P. 1992. Patterns of wetland use among aquatic birds in the interior boreal forest of Alaska. Ph.D. dissertation, Univ. of Mo., Columbia.

Kessel, B., and Gibson, D. D. 1978. Status and distribution of Alaska birds. Studies Avian Biol. 1.

Kessel, B., and Springer, H. K. 1966. Recent data on status of some interior Alaska birds. Condor 68:185-195; doi 10.2307/1365717.

Lewis, T. L., Lindberg, M. S., Schmutz, J. A., Bertram, M. R., and Dubour, A. J. 2015. Species richness and distribution of boreal waterbird broods in relation to nesting and brood-rearing habitats. J. Wildl. Mgmt. 79:296-310; doi 10.1002/ jwmg. 837.

Martin, P. R., Bonier, F., and Gibson, D. D. 2006. First nest of the Yellow-bellied Flycatcher for Alaska, with notes on breeding biology. W. Birds 37:8-22.

Person, D., and Bertram, M. 1999. Waterfowl brood survey in the southern Yukon Flats. U. S. Fish and Wildlife Service, Fairbanks, AK.

Schmidt, J. H., Lindberg, M. S., Johnson, D. S., Conant, B., and King, J. 2009. Evidence of Alaskan Trumpeter Swan Population Growth Using Bayesian Hierarchical Models. J. Wildl. Mgmt. 73:720-727; doi 10.2193/2008-262.

Shively, R. D., and Lake, B. C. 2009. Brood surveys of Yukon Flats National Wildlife Refuge and Tetlin Region-1965-1981. U. S. Fish and Wildlife Service, Fairbanks, AK.

Sinclair, P. H., Nixon, W. A., Eckert, C. D., and Hughes, N. L. (eds.) 2003. Birds of the Yukon Territory. Univ. Br. Columbia Press, Vancouver.

Tobish, T. G. Jr. 1993. Alaska Region (summer 1993). Am. Birds 47:1138-1140.

Tobish, T. [G. Jr.]. 2006. Alaska Region (fall 2005). N. Am. Birds 60:119-123.

Tobish, T. [G. Jr.]. 2007. Alaska Region (fall 2006). N. Am. Birds 61:122-126.

Tobish, T. [G. Jr.]. 2008. Alaska Region (fall 2007). N. Am. Birds 62:129-135.

Tobish, T. [G. Jr.]. 2010. Alaska Region (summer 2009). N. Am. Birds 63:638-642.

Tobish, T. [G. Jr.]. 2011. Alaska Region (summer 2010). N. Am. Birds 64:632-635.

Tobish, T. [G. Jr.]. 2012. Alaska Region (fall 2011). N. Am. Birds 66:146-152.

Tobish, T. G. Jr., and Isleib, M. E. 1993. Alaska Region (autumn 1992). Am. Birds 47:133-136.

Willett, G. 1921. Bird notes from southeastern Alaska. Condor 23:156-159; doi $10.2307 / 1362724$.

Winker, K., and Gibson, D. D. 2018. Some broad-scale effects of recent and future climate change among migratory birds in Beringia, in Trends and traditions: Avifaunal change in western North America (W. D. Shuford, R. E. Gill Jr., and C. M. Handel, eds.), pp. 432-440. Studies of Western Birds 3. W. Field Ornithol., Camarillo, CA; doi 10.21199/SWB3.23.

Accepted 11 June 2019 